\title{
RESEARCH NOTE \\ Yield and nitrogen recovery of wheat plants subjected to urea application with or without a urease inhibitor in the absence of irrigation
}

\author{
Marcelo C. Espindula', Marcela Campanharo², Jairo R. M. Dias ${ }^{2}$, Valterley \\ S. Rocha ${ }^{3}$, Moacil A. de Souza ${ }^{3}$, and Giovana Menoncin ${ }^{4}$ \\ ${ }^{1}$ Embrapa Rondônia, BR 364, Km 5,5, CEP 76815-800, Porto Velho, Rondônia, Brasil. \\ 2Universidade Federal de Rondônia, Departamento de Agronomia, Avenida Norte Sul, $n^{\circ} 7.300$, Nova \\ Morada, CEP 76940-000 Rolim de Moura, Rondônia, Brasil. \\ 3 Universidade Federal de Viçosa, Departamento de Fitotecnia, Av. P.H. Rolfs, s/n, 36570-000, Viçosa, \\ Minas Gerais, Brasil. \\ 4Universidade Federal de Rondônia, Programa de Pós Graduação em Ciências Ambientais, Avenida Norte \\ Sul, n 7.300, Nova Morada, CEP 76940-000 Rolim de Moura, Rondônia, Brasil.
}

\begin{abstract}
M.C. Espindula., M. Campanharo, J.R.M. Dias, V.S. Rocha, M.A. de Souza, and G. Menoncin. 2016. Yield and nitrogen recovery of wheat plants subjected to urea application with or without a urease inhibitor in the absence of irrigation. Cien Inv. Agr. 43(2):317-325. The use of urease inhibitors and irrigation are management options to increasing the efficiency of top-dressed urea by reducing $\mathrm{NH}_{3}$ volatilization. The purpose of this study was to evaluate the productive performance and $\mathrm{N}$ recovery of 'BRS 254 ' wheat plants without irrigation after applying urea or urea+NBPT [N-(n-butyl)thiophosphoric triamide] as the top dressing. The experiment was carried out in Viçosa, MG, Brazil, between May and September of 2008 using a complete randomized block design with a $2 \times 6+1$ factorial arrangement of the following treatments: 1 ) urea or urea+NBPT, 2) six periods without irrigation $(0,48,96,144,192$ or $240 \mathrm{~h}$ after applying the top-dressing fertilizer), and 3) a control without $\mathrm{N}$; there were four replications. The data were subjected to an analysis of variance $(\mathrm{P} \leq 0.05)$. The mean values of the treatments with urea or urea + NBPT were compared by Tukey's test $(\mathrm{P} \leq 0.05)$, and the effects of the periods without irrigation were analyzed by a regression $(\mathrm{P} \leq 0.05)$. The results of the study show that NBPT did not lead to agronomic advantages for the wheat crop under the study conditions, and the absence of irrigation after urea application as the top dressing led to less $\mathrm{N}$ utilization by the wheat plants.
\end{abstract}

Key words: Triticum aestivum, nitrogen fertilization, nitrogen recovery, volatilization of $\mathrm{NH}_{3}$.

\section{Introduction}

Urea $\left[\mathrm{CO}\left(\mathrm{NH}_{2}\right)_{2}\right]$ is the main form of nitrogen fertilizer used in agriculture. Plants may uptake $\mathrm{N}$ in the form of urea through their roots, but they preferentially uptake the ammonia $\left(\mathrm{NH}_{4}^{+}\right)$

Received: April 25, 2015. Accepted July 15, 2016. Corresponding author: marcelo.espindula@embrapa.br produced from the urea through the action of the urease enzyme (Krajewska, 2009) or the nitrate $\left(\mathrm{NO}_{3}^{-}\right)$(Bredemeier and Mundstock, 2000) produced from the oxidation of $\mathrm{NH}_{4}^{+}$.

Ureases are enzymes that are ubiquitous in nature. They are synthesized by numerous organisms, including plants, bacteria, algae, fungi and in- 
vertebrates, and they also occur as soil enzymes. Due to their widespread occurrence, ureases play an important role in the global metabolism of nitrogen (Krajewska, 2009).

Urea is the readily available substrate for the reaction catalyzed by urease that produces ammonia $\left(\mathrm{NH}_{3}\right)$, and this gas is subject to volatilization (Malhi et al., 2001; Mérigout et al., 2008).

The volatilization of $\mathrm{NH}_{3}$ in soil increases in response to the factors that increase evaporation, such as high air and soil temperatures and high winds (Malhi et al., 2001). The application of urea in dry soils, in the absence of rain, results in reduced urea dissolution and hydrolysis; however, as the moisture increases, the hydrolysis also increases such that the volatilization also increases (Prasertsak et al., 2001). Nevertheless, volatilization can be reduced if there is sufficient rain or irrigation to allow the incorporation of urea into the soil (Prasertsak et al., 2001; Cantarella et al., 2008).

The greatest $\mathrm{NH}_{3}$ volatilization occurs within the first three days after urea application; therefore, the application of irrigation water soon after fertilization is a strategy for incorporating urea into the soil, thus reducing losses and increasing fertilization efficiency, as long as the $\mathrm{N}$ remains accessible to the plants (Duarte et al., 2007). However, irrigation is not always available, and rains do not reliably fall immediately after fertilization. Thus, an alternative is the use of urease activity inhibitors.

The use of urease activity inhibitors is a management option to increase the efficiency of urea applied to the surface through the reduction of volatilization (Krajewska, 2009). Among these inhibitors, NBPT [N-(n-butyl)thiophosphoric triamide] stands out as a promising agent for the reduction of $\mathrm{NH}_{3}$ volatilization (Malhi et al., 2001; Gioacchini et al., 2002; Cantarella et al., 2008; Giovannini et al., 2009; Marchesan et al., 2013; Espindula et al., 2013).
The NBPT inhibitor occupies the urease active site, making it inactive (Krajewska, 2009), and this slows the onset and the rate of urea hydrolysis and, consequently, the volatilization peaks (Tasca et al., 2011). Delaying hydrolysis reduces the content of $\mathrm{NH}_{3}$ in the soil surface, reducing the potential for volatilization until the fertilizer is incorporated into the soil.

In Central Brazil, wheat cropping mainly occurs in the months from May to September, during which both the temperature and rainfall decrease; therefore, the crops must be irrigated to ensure greater productive efficiency. However, many farmers opt for rainfed cultivation; therefore, the purpose of this study was to evaluate the productive performance and $\mathrm{N}$ recovery of wheat plants after the application of urea or urea+NBPT as the top dressing in the absence of irrigation.

\section{Materials and methods}

The experiment was conducted at the Prof. Diogo Alves de Mello Experimental Station of the Universidade Federal de Viçosa-UFV (Federal University of Viçosa) in Viçosa, MG (204' S and $42^{\circ} 51^{\prime} \mathrm{W}$; altitude of $650 \mathrm{~m}$ ) between May and September 2008. Daily maximum, mean and minimum temperatures; relative air humidity; wind speed and rainfall during the experimental period were obtained from the main climatological station of the UFV Agricultural Engineering Department (Figure 1).

The soil of the study area is a red-yellow oxisol that has been planted with soybeans (summer) and wheat (winter) for the last ten years. The chemical and physical characteristics of this soil were determined from the 0 to 20 -cm layer (Table 1) following the methodology of Embrapa (2009).

The soil was prepared by plowing and two-disk harrowing, and fertilization was performed at planting with $300 \mathrm{~kg} \mathrm{ha}^{-1}$ of the commercial formula 08-28-16 (24 kg N ha-1). 'BRS 254' wheat 
Table 1. Chemical and physical characteristics of the red-yellow oxisol of the Prof. Diogo Alves de Mello Experimental Station.

\begin{tabular}{|c|c|c|c|c|c|c|c|c|c|c|c|}
\hline \multicolumn{12}{|c|}{ Chemical characteristics } \\
\hline \multirow[b]{2}{*}{$\mathrm{pH} \mathrm{H} \mathrm{H}_{2} \mathrm{O}$} & $\mathrm{P}$ & $\mathrm{K}$ & $\mathrm{Ca}^{2+}$ & $\mathrm{Mg}^{2+}$ & $\mathrm{Al}^{3+}$ & $\mathrm{H}+\mathrm{Al}$ & SB & $\mathrm{CEC}(\mathrm{t})$ & $\mathrm{CEC}(\mathrm{T})$ & \multirow[b]{2}{*}{$\mathrm{V}(\%)$} & \multirow[b]{2}{*}{$\mathrm{OM} \mathrm{g} \mathrm{kg}^{-1}$} \\
\hline & \multicolumn{2}{|c|}{$\mathrm{mg} \mathrm{dm}{ }^{-3}$} & \multicolumn{7}{|c|}{$\mathrm{cmol}_{\mathrm{c}} \mathrm{dm}^{-3}$} & & \\
\hline 5.5 & 24.1 & 140 & 2.9 & 0.6 & 0.0 & 3.80 & 3.86 & 3.86 & 7.66 & 50 & 17 \\
\hline \multicolumn{12}{|c|}{ Physical characteristics } \\
\hline & Sand & Silt & Clay & & \multirow{2}{*}{\multicolumn{3}{|c|}{ Texture class }} & \multirow{2}{*}{\multicolumn{2}{|c|}{ Density $\left(\mathrm{kg} \mathrm{dm}^{-3}\right)$}} & $\mathrm{FC}$ & WP \\
\hline & & $\mathrm{g} \mathrm{kg}^{-1}$ & & & & & & & & \multicolumn{2}{|c|}{$\mathrm{kg} \mathrm{kg}^{-1}$} \\
\hline & 300 & 170 & 530 & & & clay & & 1.0 & & 0.372 & 0.221 \\
\hline
\end{tabular}

$\mathrm{pH}\left(\mathrm{H}_{2} \mathrm{O}-1: 2.5\right) ; \mathrm{Ca}^{2+}, \mathrm{Mg}^{2+}$ and $\mathrm{Al}^{3+}: 1 \mathrm{~mol} \mathrm{~L}^{-1} \mathrm{KCl}$ extractor; $\mathrm{P}$ and $\mathrm{K}$ : Mehlich ${ }^{-1}$ extractor; $\mathrm{H}+\mathrm{Al}: 0.5 \mathrm{~mol} \mathrm{~L}^{-1} \mathrm{calcium}^{2}$ acetate extractor at $\mathrm{pH}$ 7.0. SB: sum of bases; $\mathrm{CEC}(\mathrm{t})$ : effective cation exchange capacity; CEC(T): cation exchange capacity to $\mathrm{pH}$ 7.0; V: base saturation; OM: organic matter; FC: field capacity; WP: wilting point.
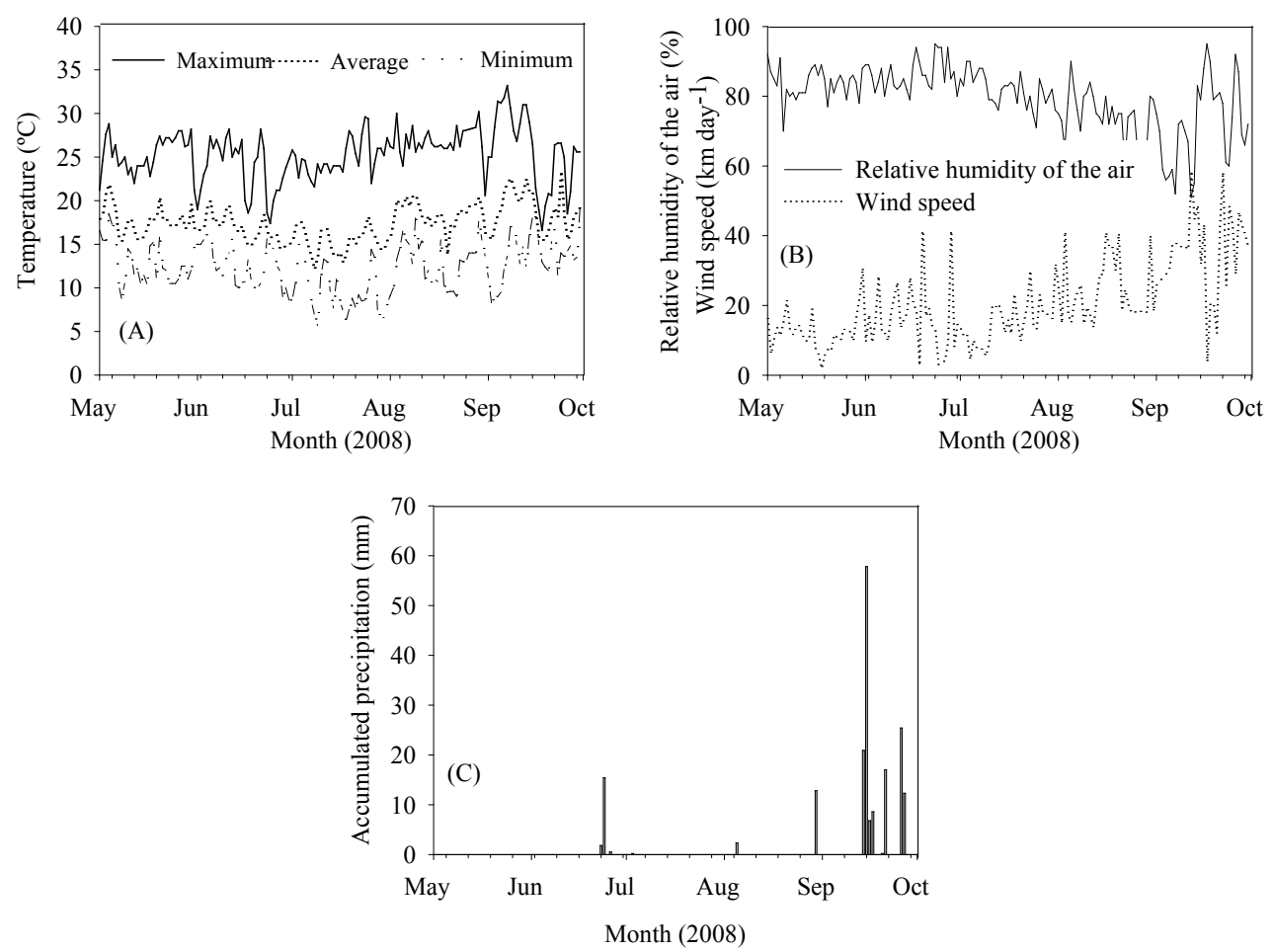

Figure 1. Temperatures: maximum, mean and minimum (A); relative humidity and wind speed (B); and rainfall (C) from May-September 2008. Viçosa, MG, Brazil.

seeds were sown at a density of 350 viable useful seeds per $\mathrm{m}^{2}$ with a seeder designed for experimental plots.

Treatments were arranged in a $2 \times 6+1$ factorial arrangement in which urea or urea+NBPT $[\mathrm{N}-$ (n-butyl)thiophosphoric triamide] (Agrotain ${ }^{\circledR}$
Saint Louis, MO, USA) were applied in a liquid form at a rate of $530 \mathrm{mg} \mathrm{kg}^{-1}$ in combination with six periods of no irrigation as follows: $0,48,96$, $144,192,240 \mathrm{~h}$ after fertilizer application as the top dressing. In addition, a control without $\mathrm{N}$ application plus irrigation during the first time period was established. The experimental design 
was a randomized block with four replications, and the experimental plot consisted of nine rows of $5 \mathrm{~m}$ in length spaced $0.20 \mathrm{~m}$ apart. The useful area of the plot, $2.4 \mathrm{~m}^{2}$, consisted of three rows; $0.5 \mathrm{~m}$ at both ends were eliminated.

Top-dressing fertilization was carried out 16 days after seedling emergence, when the plants were at the beginning of the tillering stage, using a $100 \mathrm{~kg} \mathrm{ha}^{-1}$ dose of $\mathrm{N}$ that was established in an experiment performed the previous year. At the time of the top-dressing fertilization, the soil had a moisture level of $25 \%$ of field capacity. Irrigation (during the application of the treatments) was carried out by gradually applying $20 \mathrm{~mm}$ of water with a manual sprinkler and avoiding surface runoff to the outside of the experimental plot. In addition to the irrigation treatments, four 20 -mm irrigations were performed during the crop cycle including one during sowing, another 20 days after top-dressing fertilization, another during the boot stage and the last during the grain filling stage.

At harvest, the grains were evaluated based on the agronomic characteristics of the wheat, specifically, the number of kernels per head, the shoot dry matter, the harvest index, the thousand-grain mass, the hectoliter mass and the grain yield.

The number of kernels per ear, the shoot dry matter and the harvest index (the ratio of the grain yield to the shoot dry matter) were determined for 100 stems that were collected in sequence from the center row of the plot. The thousand-grain mass was determined as the mean of eight replications of 100 grains with extrapolation to 1,000 grains. The hectoliter mass was determined using a precision balance based on the grains collected from the plants within the useful plot area, and the grain yield at $13 \%$ moisture was determined based on the grains collected from the plants within the useful plot area and converted to $\mathrm{kg} \mathrm{ha}^{-1}$.

The recovery of $\mathrm{N}$ by the wheat plants was also determined by evaluating the $\mathrm{N}$ concentration and
$\mathrm{N}$ content in the plant shoots at tillering (before top-dressing fertilization), flowering and maturity as well as the $\mathrm{N}$ concentration and $\mathrm{N}$ content in the grains. Evaluations at tillering were performed using 20 randomly selected plants from within the useful plot area; evaluations at flowering were performed using 10 randomly selected plants from within the useful plot area; and evaluations at maturity were performed using samples taken from 100 stems collected for the determination of the agronomic characteristics described above. The $\mathrm{N}$ concentration was determined by the Kjeldahl method (Embrapa, 2009), and the $\mathrm{N}$ contents in the above-ground part and the grains were determined by multiplying the $\mathrm{N}$ concentrations in these compartments by their dry matter contents.

The data were subjected to analysis of variance ( $\mathrm{P} \leq 0.05)$ using the Genes Program (Cruz, 2008), and when significant differences were detected, the mean values of the treatments with urea or urea+NBPT were compared using Tukey's test $(\mathrm{P} \leq 0.05)$. The effects of the periods without irrigation were analyzed by regression with the mathematical models chosen according to the equations with the best fit and confirmed by the highest coefficients of determination $\left(\mathrm{R}^{2}\right)$ and by the level of significance of the regression coefficients and the regression $F$ test $(P \leq 0.05)$. In the equations, the levels of significance of the coefficients are indicated by $*(\mathrm{P} \leq 0.05)$ and $* *(\mathrm{P} \leq 0.01)$. To compare the mean values of the treatments with the control, Dunnett's test was applied $(\mathrm{P} \leq 0.05)$.

\section{Results and discussion}

The evaluated characteristics were not significantly affected by the interaction of the factors. Therefore, only the simple effects of the factors were determined, and no further statistical analyses were performed.

The urea and urea+NBPT treatments did not significantly affect any of the evaluated charac- 
teristics (Tables 2, 3 and 4). Similar results have been reported by other researchers for the grain yield in barley (Hordeum vulgare L.) (Grant and Bailey, 1999) and rice (Oryza sativa L.) (Marchesan et al., 2013) and for the grain yield, dry matter production, and $\mathrm{N}$ content in the dry matter and the grains of wheat plants subjected to urea or urea+NBPT in two types of soil (Gioacchini et al., 2002).

The similarity among the treatment results suggests that the use of urea+NBPT is not justified from an agronomic perspective, but gains resulting from the use of NBPT have been reported in the literature, such as the results reported by Chien et al. (2009) for maize (Zea mays L.), in which urea+NBPT promoted greater grain yield than urea. For wheat, Espindula et al. (2013) reported yield gains with the use of NBPT in the same location as this study; therefore, the absence of significant effects in this experiment may be related to the cropping conditions as suggested by Marchesan et al. (2013). The high humidity, low temperature and low incidence of winds (Figure 1) were unfavorable for the losses by volatilization; thus, the wheat plants had a suitable $\mathrm{N}$ supply for development.

The number of kernels per ear (Figure 2A), the $\mathrm{N}$ content at flowering (Figure 2B), the $\mathrm{N}$ concentration in the shoot (Figure 2C) and the dry matter of the grains (Figure 2D) decreased linearly as the duration of the period without irrigation increased. In contrast, as the period without irrigation increased, the $\mathrm{N}$ content in the grains increased linearly (Figure 2E). The other characteristics were not affected by the absence of irrigation.

The similarity of the urea and urea+NBPT treatment results and the absence of an effect of the periods without irrigation for most of the analyzed characteristics are related to the sufficient availability of soil nitrogen for the development of the plants and the climatic conditions not being particularly favorable for $\mathrm{NH}_{3}$ volatilization.
During the top-dressing fertilization, the average temperatures were below $20^{\circ} \mathrm{C}$ and the relative humidity was above $80 \%$, which are unfavorable conditions for ammonia volatilization (Figure 1).

With respect to $\mathrm{N}$ availability, we believe that the $\mathrm{N}$ concentrations in the soil were sufficient for normal plant development in all of the treatments; therefore, there was no deficiency of this nutrient. The reasons for this include the following: 1) the soil contained $17 \mathrm{~g} \mathrm{~kg}^{-1}$ of organic matter (Table 1), and $24 \mathrm{~kg} \mathrm{ha}^{-1}$ of $\mathrm{N}$ were added at sowing with an additional $100 \mathrm{~kg} \mathrm{ha}^{-1}$ as the top dressing; 2) the plants exhibited high $\mathrm{N}$ concentrations during development, approximately $60 \mathrm{~g} \mathrm{~kg}^{-1}$ at tillering, more than $15 \mathrm{~g} \mathrm{~kg}^{-1}$ at flowering and approximately $25 \mathrm{~g} \mathrm{~kg}^{-1}$ in the grains (Tables 3 and 4); approximately $20 \mathrm{~g} \mathrm{~kg}^{-1}$ in the flag leaf at flowering and approximately $23 \mathrm{~g} \mathrm{~kg}^{-1}$ in the grain are considered to be adequate (Lopez-Bellido $e t$ al., 2004); 3) for most of the characteristics, the treatments did not differ from the control; and 4) all of the plots were lodged due to the rainfall at the end of August and the beginning of September (Figure 1), a common occurrence in winter cereal crops, such as wheat, under high doses of N (Wang et al., 2009).

With respect to the climatic conditions, during the month of June, when top-dressing fertilization and irrigation were performed, the maximum, mean and minimum temperatures were $23.61,16.70$ and $12.53{ }^{\circ} \mathrm{C}$, respectively, and the relative air humidity and wind speed were $86.26 \%$ and $16.43 \mathrm{~km}$ day ${ }^{-1}$. These conditions are not favorable to $\mathrm{NH}_{3}$ volatilization because it increases with conditions that increase evaporation, such as high air and soil temperatures and high winds (Malhi et al., 2001). Despite the lack of favorable conditions, the volatilization of urea+NBPT was up to $12 \%$ less than that of urea (result not presented), but as has already been mentioned, the $\mathrm{N}$ availability was sufficient for plant development.

The observed decreases in the number of kernels per ear, the accumulated $\mathrm{N}$ at flowering, the $\mathrm{N}$ 
Table 2. Grain yield components of 'BRS 254' wheat plants subjected to urea or urea+NBPT and six periods of no irrigation.

\begin{tabular}{|c|c|c|c|c|c|c|c|c|c|c|c|c|}
\hline \multirow[b]{4}{*}{ Time (h) } & \multicolumn{12}{|c|}{ Characteristics evaluated $^{1}$} \\
\hline & \multicolumn{2}{|c|}{$\begin{array}{c}\mathrm{NKE}^{3} \\
----\end{array}$} & \multicolumn{2}{|c|}{$\begin{array}{c}\mathrm{HM} \\
\mathrm{kg} \mathrm{hL}^{-1}\end{array}$} & \multicolumn{2}{|c|}{$\begin{array}{c}\text { TGM } \\
\mathrm{g}\end{array}$} & \multicolumn{2}{|c|}{$\begin{array}{l}\text { Yield } \\
\mathrm{kg} \mathrm{ha}^{-1}\end{array}$} & \multicolumn{2}{|c|}{$\begin{array}{c}\text { SDM } \\
\mathrm{kg} \mathrm{ha}^{-1}\end{array}$} & \multicolumn{2}{|c|}{ HI } \\
\hline & & Ureat & & Urea+ & & Urea+ & & Urea+ & & Urea+ & & Urea+ \\
\hline & Urea & NBPT & Urea & NBPT & Urea & NBPT & Urea & NBPT & Urea & NBPT & Urea & NBPT \\
\hline 0 & $43.8^{*}$ & $43.6^{*}$ & 75.5 & 75.4 & 35.5 & 34.5 & 3805 & 3480 & 13890 & 13380 & 0.388 & 0.379 \\
\hline 48 & $40.5^{*}$ & $40.8^{*}$ & 76.0 & 75.4 & 36.0 & 34.9 & 3257 & 3861 & 13275 & 12854 & 0.361 & 0.390 \\
\hline 96 & $39.0 \mathrm{~ns}$ & $40.1^{*}$ & 75.9 & 75.8 & 35.5 & 34.7 & 3302 & 3810 & 12603 & 12921 & 0.356 & 0.355 \\
\hline 144 & $39.8 \mathrm{~ns}$ & $39.6 \mathrm{~ns}$ & 75.8 & 75.3 & 36.0 & 35.1 & 3935 & 3418 & 13652 & 13485 & 0.367 & 0.367 \\
\hline 192 & $39.3 \mathrm{~ns}$ & $37.3 \mathrm{~ns}$ & 75.6 & 75.5 & 36.1 & 36.3 & 3508 & 3968 & 13208 & 13089 & 0.372 & 0.379 \\
\hline 240 & $37.2 \mathrm{~ns}$ & $36.3 \mathrm{~ns}$ & 75.1 & 75.6 & 36.8 & 36.4 & 3450 & 3541 & 13822 & 12685 & 0.371 & 0.353 \\
\hline Cont. $^{2}$ & & .30 & & .38 & & 6.99 & & 49 & & & & 362 \\
\hline $\mathrm{CV}(\%)$ & & 92 & & 32 & & .28 & & .32 & & & & 29 \\
\hline
\end{tabular}

${ }^{1} \mathrm{NKE}$ - Number of kernels per ear; HM - Hectoliter mass; TGM - Thousand-grain mass; YIELD - Grain yield; DMS Shoot dry matter; HI - Harvest index. There were no significant differences between the fertilizers according to the results of the Tukey's test $(\mathrm{P} \leq 0.05) .{ }^{2}$ Control. ${ }^{3}$ There was only a significant effect of the control vs. the factorial interaction for NKE. *Differs from the control, and ns: does not differ from the control, according to Dunnett's test $(\mathrm{P} \leq 0.05)$.

Table 3. Nitrogen concentration and content in the above-ground part of 'BRS 254' wheat plants subjected to urea or urea+NBPT and six periods of no irrigation.

\begin{tabular}{|c|c|c|c|c|c|c|c|c|}
\hline \multirow[b]{4}{*}{ Time (h) } & \multicolumn{7}{|c|}{ Characteristics evaluated ${ }^{1}$} & \\
\hline & \multicolumn{2}{|c|}{$\begin{array}{l}\mathrm{N} \text { concentration at } \\
\text { tillering } \\
\mathrm{g} \mathrm{kg}^{-1}\end{array}$} & \multicolumn{2}{|c|}{$\begin{array}{l}\mathrm{N} \text { content at tillering } \\
\text { mg plant }^{-1}\end{array}$} & \multicolumn{2}{|c|}{$\begin{array}{l}\mathrm{N} \text { concentration at } \\
\text { flowering } \\
\mathrm{g} \mathrm{kg}^{-1}\end{array}$} & \multicolumn{2}{|c|}{$\begin{array}{c}\mathrm{N} \text { content at flowering } \\
\text { mg plant }^{-1}\end{array}$} \\
\hline & & Urea+ & & Urea+ & & Urea+ & & Urea+ \\
\hline & Urea & NBPT & Urea & NBPT & Urea & NBPT & Urea & NBPT \\
\hline 0 & 62.13 & 61.44 & 3.63 & 3.31 & $19.18^{*}$ & $17.89 \mathrm{~ns}$ & $51.85^{*}$ & $47.79 *$ \\
\hline 48 & 60.05 & 60.57 & 3.09 & 3.28 & $18.49^{*}$ & $19.58^{*}$ & $49.58^{*}$ & $51.78^{*}$ \\
\hline 96 & 62.30 & 61.78 & 3.30 & 3.19 & $17.28 \mathrm{~ns}$ & $18.15^{*}$ & $45.51 \mathrm{~ns}$ & $47.23^{*}$ \\
\hline 144 & 60.38 & 60.05 & 3.29 & 3.47 & $17.02 \mathrm{~ns}$ & $18.41^{*}$ & $43.43 \mathrm{~ns}$ & $47.52 *$ \\
\hline 192 & 62.13 & 63.16 & 3.39 & 3.62 & $16.71 \mathrm{~ns}$ & $17.69 \mathrm{~ns}$ & $40.13 \mathrm{~ns}$ & $45.30 \mathrm{~ns}$ \\
\hline 240 & 62.82 & 59.02 & 3.42 & 3.27 & $16.22 \mathrm{~ns}$ & $17.27 \mathrm{~ns}$ & $38.52 \mathrm{~ns}$ & $43.38 \mathrm{~ns}$ \\
\hline Cont. $^{2}$ & \multicolumn{2}{|c|}{59.54} & \multicolumn{2}{|c|}{3.08} & \multicolumn{2}{|c|}{15.08} & \multicolumn{2}{|c|}{36.26} \\
\hline $\mathrm{CV}(\%)$ & \multicolumn{2}{|c|}{3.06} & \multicolumn{2}{|c|}{10.92} & \multicolumn{2}{|c|}{8.43} & \multicolumn{2}{|c|}{10.84} \\
\hline
\end{tabular}

${ }^{1}$ There were no significant differences between the fertilizers according to Tukey's test $(\mathrm{P} \leq 0.05) .{ }^{2} \mathrm{Control}$. *Differs from the control, and ns: does not differ from the control according to Dunnett's test $(\mathrm{P} \leq 0.05)$.

content in the vegetative shoots at maturity and the dry matter of the grain (Figures 2A, 2B, 2C and $2 \mathrm{D}$, respectively) suggest less $\mathrm{N}$ recovery by the plants from which irrigation was withheld for longer periods of time. However, the increase in the $\mathrm{N}$ concentration in the grain (Figure 2E) is related to the concentration of this nutrient because the number of kernels per ear and the dry matter of the grain decreased as the time without irrigation increased. This concentration/dilution effect is common in wheat plants (Acreche and Slafer, 2009) and has also been reported for Triticum dicoccum (Schübler), for which doses of $\mathrm{N}$ simultaneously led to a lower thousand-grain weight and a greater concentration of $\mathrm{N}$ in the grain (Marino et al., 2009). 

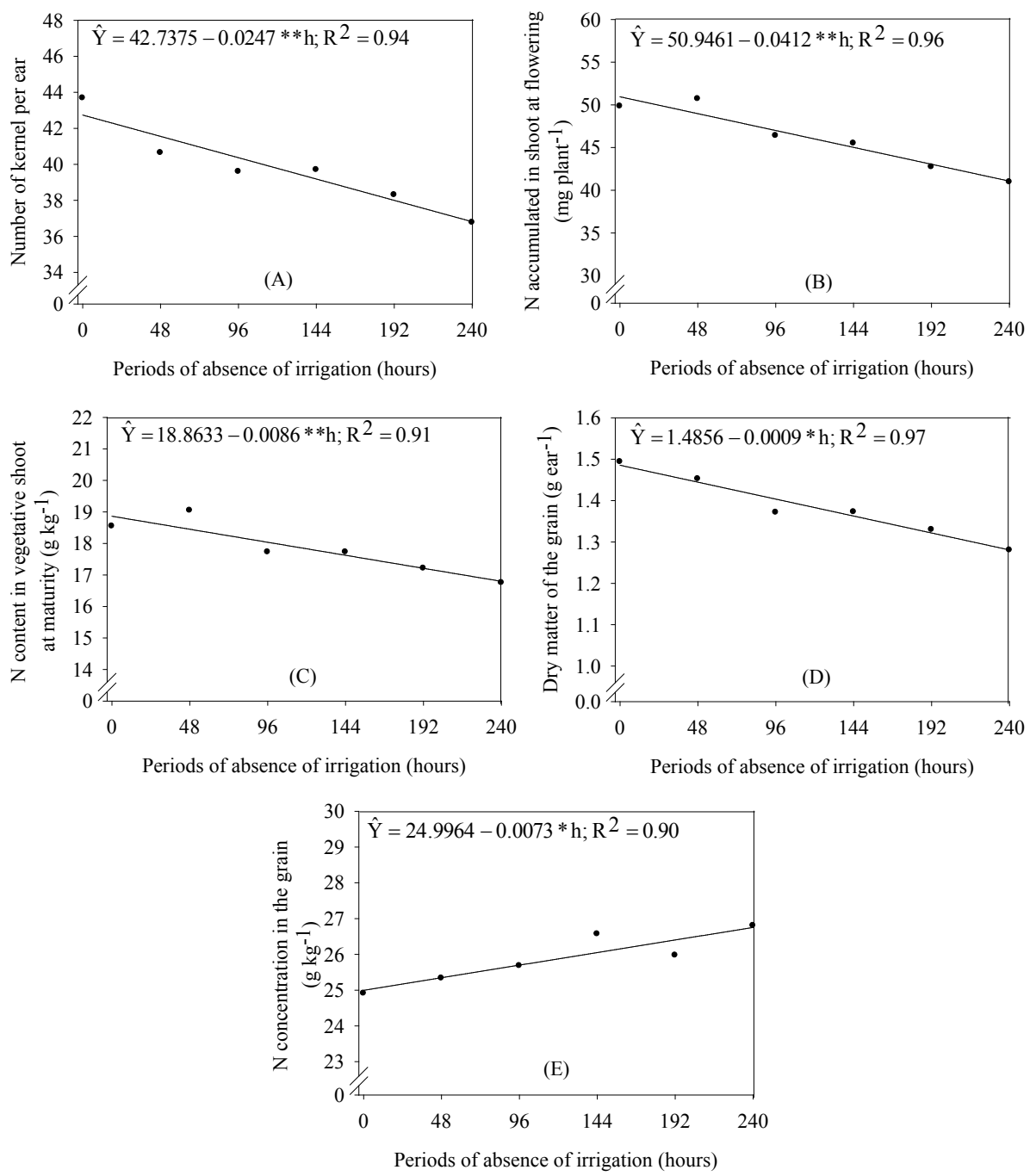

Figure 2. Number of kernels per head (A), $N$ content in the shoots at flowering (B), $N$ concentration in the shoots at maturity (C), dry matter of the grain (D), and N concentration in the grain (E) of 'BRS 254' wheat plants subjected to six periods without irrigation after top-dressing nitrogen fertilization.

Although few characteristics were affected by the absence of irrigation, the results indicate that shorter times between the top-dressing application of urea and irrigation resulted in better $\mathrm{N}$ utilization.

Under the study conditions, NBPT does not lead to agronomic advantages for the wheat crop.

The absence of irrigation after the top-dressing application of urea leads to reduced $\mathrm{N}$ utilization by wheat plants.

\section{Acknowledgments}

Gratitude is expressed to the "Conselho Nacional de Desenvolvimento Científico e Tecnológico" (CNPq) and the "Fundação de Amparo à Pesquisa do Estado de Minas Gerais" (FAPEMIG, Brazil) for the scholarships and fellowships and to Fertipar Sudeste Adubos e Corretivos Agrícolas Ltda and Agrotain International LLC for their support. 
Table 4. Nitrogen concentration and content in the above-ground matter and the grains of the 'BRS 254' wheat plants subjected to urea or urea+NBPT and six periods of no irrigation.

\begin{tabular}{|c|c|c|c|c|c|c|c|c|}
\hline \multirow[b]{3}{*}{ Time (h) } & \multicolumn{6}{|c|}{ Characteristics evaluated $^{1}$} & & \\
\hline & \multicolumn{2}{|c|}{$\begin{array}{l}\mathrm{N} \text { concentration at } \\
\text { maturity } \\
\mathrm{g} \mathrm{kg}^{-1}\end{array}$} & \multicolumn{2}{|c|}{$\begin{array}{l}\mathrm{N} \text { content at } \\
\text { maturity } \\
\text { mg plant }^{-1}\end{array}$} & \multicolumn{2}{|c|}{$\begin{array}{l}\mathrm{N} \text { concentration of } \\
\text { grains } \\
\mathrm{g} \mathrm{kg}^{-1}\end{array}$} & \multicolumn{2}{|c|}{$\begin{array}{l}\mathrm{N} \text { content of grains } \\
\text { mg ear }^{-1}\end{array}$} \\
\hline & Urea & $\begin{array}{l}\text { Urea+ } \\
\text { NBPT }\end{array}$ & Urea & $\begin{array}{l}\text { Urea+ } \\
\text { NBPT }\end{array}$ & Urea & $\begin{array}{l}\text { Urea+ } \\
\text { NBPT }\end{array}$ & Urea & $\begin{array}{l}\text { Urea+ } \\
\text { NBPT }\end{array}$ \\
\hline 0 & $6.30^{\mathrm{ns}}$ & $7.55^{\mathrm{ns}}$ & $16.55^{\text {ns }}$ & $17.88^{\mathrm{ns}}$ & $24.31^{\mathrm{ns}}$ & $25.49^{*}$ & $37.34 *$ & $37.10^{*}$ \\
\hline 48 & $7.46^{\mathrm{ns}}$ & $9.35^{*}$ & $18.08^{\mathrm{ns}}$ & $22.74 *$ & $24.89^{\text {ns }}$ & $25.75^{*}$ & $36.91 *$ & $36.70^{*}$ \\
\hline 96 & $7.94^{\mathrm{ns}}$ & $8.47 *$ & $20.33 *$ & $19.99 *$ & $25.94 *$ & $25.41 *$ & $35.82 *$ & $34.53 *$ \\
\hline 144 & $7.63^{\mathrm{ns}}$ & $9.72 *$ & $18.30^{\text {ns }}$ & $23.03 *$ & $25.93 *$ & $27.20^{*}$ & $35.43 *$ & $37.48^{*}$ \\
\hline 192 & $8.17^{\mathrm{ns}}$ & $9.16^{*}$ & $19.39^{\text {ns }}$ & $21.32 *$ & $26.18^{*}$ & $25.75^{*}$ & $35.63 *$ & $33.59^{\text {ns }}$ \\
\hline 240 & $7.50^{\mathrm{ns}}$ & $9.13 *$ & $18.63^{\mathrm{ns}}$ & $20.66^{*}$ & $27.66^{*}$ & $25.93 *$ & $36.64 *$ & $31.90^{\text {ns }}$ \\
\hline Cont. $^{2}$ & \multicolumn{2}{|c|}{5.23} & \multicolumn{2}{|c|}{11.65} & \multicolumn{2}{|c|}{22.93} & \multicolumn{2}{|c|}{26.66} \\
\hline $\mathrm{CV}(\%)$ & \multicolumn{2}{|c|}{18.67} & \multicolumn{2}{|c|}{20.75} & \multicolumn{2}{|c|}{4.80} & \multicolumn{2}{|c|}{10.20} \\
\hline
\end{tabular}

${ }^{1}$ There were no significant differences among fertilizers according to Tukey's test $(\mathrm{P} \leq 0.05) .{ }^{2}$ Control. $*$ Differs from the control, and ${ }^{\text {ns }}$ does not differ from the control according to Dunnett's test $(\mathrm{P} \leq 0.05)$.

\section{Resumen}

M.C. Espíndula, M. Campanharo, J.R.M. Dias, V.S. Rocha, M.A. de Souza y G. Menoncin. 2016. Rendimiento y recuperación del nitrógeno por las plantas de trigo sometido la aplicación de la urea con o sin inhibidor de la ureasa en ausencia de riego. Cien. Inv. Agr. 43(2):317-325. El uso de inhibidores de ureasa o de riego son opciones de manejo para aumentar la eficiencia de la urea aplicada en cobertera, a través de la reducción de la volatilización de $\mathrm{NH}_{3}$. La investigación tuvo como objetivo la evaluación del desempeño productivo y la recuperación de N por plantas de trigo 'BRS 254' sin riego, después de la aplicación de urea o urea+ NBPT [N-(n-butyl)thiophosphoric triamide] en cobertera. El experimento se llevó a cabo en la ciudad de Viçosa, MG, en Brasil desde mayo hasta septiembre de 2008. Los tratamientos siguieron un arreglo factorial $2 \times 6+1$, en el cual la urea o urea + NBPT se combinaron en seis periodos sin riego: $0,48,96,144,192$ y 240 horas después de la aplicación del fertilizante en cobertera, además de una muestra de control sin la aplicación de N. Para el diseño experimental, se utilizaron los bloques completos al azar con cuatro repeticiones. Se concluyó que el NBPT no proporciona ventajas agrícolas a la cosecha de trigo, bajo las condiciones estudiadas. La ausencia de riego después de la aplicación de urea en cobertera provee un aprovechamiento menor de $\mathrm{N}$ por las plantas de trigo.

Palabras clave: Triticum aestivum, fertilización nitrogenada, recuperación de nitrógeno, volatilización de $\mathrm{NH}_{3}$.

\section{References}

Acreche, M. M., and G. A. Slafer. 2009 Variation of grain nitrogen content in relation with grain yield in old and modern Spanish wheat grown under a wide range of agronomic conditions in a Mediterranean region. J. Agr. Sci. 147:657-667.
Bredemeier, C., and C. M. Mundstock. 2000. Regulação da absorção e assimilação do nitrogênio nas plantas. Ciência Rural 30:365-372.

Cantarella, H., P. C. O. Trivelin, T. L. M. Contin, F. L. F. Dias, R. Rossetto, R. Marcelino, R. B. Coimbra, and J. A. Quaggio. 2008. Ammonia volatilization from urease inhibitor-treated urea 
applied to sugarcane trash blankets. Sci. Agricola 65: 397-401.

Chien, S. H., L. I. Prochnow, and H. Cantarella. 2009. Recent developments of fertilizer production and use to improve nutrient efficiency and minimize environmental impacts. Adv. Agron. 102:267-322.

Cruz, C. D. Programa Genes - Diversidade Genética. 1. ed. Viçosa, MG: Editora UFV, 2008. v. 1. 278 p.

Duarte, F. M., E. Pocojeski, L. S. Silva, F. A. Graupe, and D. Britzke. 2007. Perdas de nitrogênio por volatilização de amônia com aplicação de uréia em solo de várzea com diferentes níveis de umidade. Ciê. Rural 37:705-711.

EMBRAPA. 2009. Manual de análises químicas de solos, plantas e fertilizantes. Empresa Brasileira de Pesquisa Agropecuária. 2. ed. Brasília, DF. 309 pp.

Espindula, M. C., V. S. Rocha, M. A. Souza, M. Campanharo, and G. S. Paula. 2013. Rates of urea with or without urease inhibitor for topdressing wheat. Chil. J. Agr. Res. 73:160-167.

Gioacchini, P., A. Nastri, C. Marzadori, C. Giovannini, L. V. Antisari, and C. Gessa. 2002. Influence of urease and nitrification inhibitors on $\mathrm{N}$ losses from soils fertilized with urea. Biol. Fert. Soils 36:129-135.

Giovannini, C., J. M. Garcia-Mina, C. Ciavatta, and C. Marzadori. 2009. Ureic nitrogen transformation in multi-layer soil columns treated with urease and nitrification inhibitors. J. Agr. Food Chem. 57:4883-4887.

Grant, C. A., and L. D. Bailey. 1999. Effect of seedplaced urea fertilizer and n-(n-butyl) thiophosphoric triamide (NBPT) on emergence and grain yield of barley. Can. J. Plant Sci. 79:491-496.
Krajewska, B. 2009. Ureases I. Functional, catalyctic and kinetic properties: A review. J. Mol. Cat. B: Enz. 59:9-21.

Lopez-Bellido, R. J., C. E. Shepherd, and P. B. Barraclough. 2004. Predicting post-anthesis N requirements of bread wheat with a Minolta SPAD meter. Eur. J. Agr. 20:313-320.

Malhi, S. S., C. A. Grant, A. M. Johnston, and K. S. Gill. 2001. Nitrogen fertilization management for no-till cereal production in the Canadian Great Plains: a review. Soil Til. Res. 60:101-122. Marchesan, E., M. Grohs, M. Walter, L. S. Silva, and T. C. Formentini. 2013. Agronomic performance of rice to the use of urease inhibitor in two cropping systems. Rev. Ciê. Agr. 44:594-603.

Marino, S., R. Tognetti, and A. Alvino. 2009. Crop yield and grain quality of emmer populations grown in central Italy, as affected by nitrogen fertilization. Eur. J. Agr. 31:233-240.

Mérigout, P., M. Lelandais, F. Bitton, J. P. Renou, X. Briand, C. Meyer, and F. Daniel-Vedele. 2008. Physiological and transcriptomic aspects of urea uptake and assimilation in Arabidopsis plants. Plant Phys. 147:1225-1238.

Prasertsak, P., J. R. Freney, P. G. Saffigna, O. T. Denmead, and B. G. Prove. 2001. Fate of urea nitrogen applied to a banana crop in the wet tropics of Queensland. Nut. Cycl. Agr. 59:65-73.

Tasca, F. A., P. R Ernani, D. A. Rogeri, L.C. Gatibori, and P.C. Cassol. Volatilização de amônia do solo após aplicação de ureia convencional ou com inibidor de urease. Revista Brasileira de Ciência do Solo, Viçosa, v. 35, n. 6, p. 493 - 502, nov./ dez., 2011.

Wang, F., Z. He, K. Sayre, S. Li, J. Si, B. Feng, and L. Kong. 2009. Wheat cropping systems and technologies in China. F. Crops Res. 111:181-188. 
